American Journal of Agricultural and Biological Sciences 5 (2): 194-203, 2010

ISSN 1557-4989

(C) 2010 Science Publications

\title{
Effect of Maturity Stage of Papaya Maradol on Physiological and Biochemical Parameters
}

\author{
${ }^{1,2}$ Laura E. Gayosso-García Sancho, ${ }^{3}$ Elhadi M. Yahia, \\ ${ }^{1}$ Miguel Angel Martínez-Téllez, and ${ }^{1}$ Gustavo Adolfo González-Aguilar \\ ${ }^{1}$ Coordination of Food Technology of Plant Origin, \\ Research Center for Food and Development, AC Km 0.6, \\ Road to Victory, AP 1735, 83000, Hermosillo, Sonora, Mexico \\ ${ }^{2}$ Graduate Center of the State of Sonora, Federal Labor Law S/N, \\ CP 83000, Hermosillo, Sonora, Mexico \\ ${ }^{3}$ Faculty of Natural Sciences, Universidad Autónoma de Queretaro, \\ Avenue of Science S/N, 76230, Juriquilla, Queretaro, Qro., Mexico
}

\begin{abstract}
Problem statement: Nowadays, the worldwide increase in diseases has motivated consumers to increase the intake of fruits and vegetables, in response to various research reports indicating that fruits and vegetables can help prevent certain types of illnesses, due to their potentially high antioxidant properties. We evaluated the effect of the stage of ripeness of papaya fruit (Carica papaya L.) on the contents of bioactive components and their relation with antioxidant capacity. Approach: Whole papaya fruit were selected based on their visual ripeness, classifying them in four stages of ripeness (R1, R2, R3 and R4). Physiological and physical-chemical analysis performed included respiration, production of ethylene, firmness, $\mathrm{pH}$, titratable acidity and total soluble solids, color ( $\left.\mathrm{L}^{*}, \mathrm{a}^{*}, \mathrm{~b}^{*},{ }^{\circ} \mathrm{Hue}, \mathrm{C}\right)$; Polygalacturonase (PG) and Pectin Methyl Esterase (PME) activity, total phenolic content and antioxidant capacity (measured using DPPH, TEAC and ORAC assays). Results: The antioxidant capacity decreased approximately $27 \%$ in the RS4 when using DPPH and TEAC and increased when using ORAC (60.9\%). PG activity increased from 8.14 (in $\mathrm{RS} 1$ )-22.48 $\mathrm{U} \mathrm{gFW}^{-1}$ (in RS4) as the stage of ripeness of papaya fruit increased. PME was affected in a similar manner with an activity of $0.5562 \mathrm{U} \mathrm{gFW}^{-1}$, at the end of the ripening storage. A high correlation between PG activity and softening of ripen papayas was observed. Conclusion/Recommendations: It was observed that papaya fruit experienced changes in firmness, which is correlated with activity from two of the main enzymes: PG and PME and with the increase of respiration and production of ethylene. The various stages of ripeness showed very good antioxidant capacity, being higher in RS1, which is correlated with the higher content of phenolic contents found in this ripening stage.
\end{abstract}

Key words: Carica papaya, postharvest, antioxidants, phenols, antioxidant capacity

\section{INTRODUCTION}

In the last years, several experimental, clinical and epidemiologist studies have demonstrated that fruits and vegetables contain bioactive compounds with antioxidant and antimicrobial capacity, from different chemical classes such as phenolic compounds, carotenoids, vitamins Gonzalez-Aguilar et al. (2008). These were shown to help prevent cardiovascular diseases (Hu, 2003), atherosclerosis, decrease the risk of some types of cancers, among other health benefits (Yahia, 2009).

Papaya is one of the tropical fruits with important antioxidant properties and is also in great demand in international markets. In 2008, Mexico produced about 800,000 tons, of which, the Mexican states of Veracruz and Chiapas contributed with approximately 50\% (SAGARPA, 2008). Antioxidant capacity of fruits and vegetables could be affected by a variety of factors, such as: cultivar, agronomic conditions, post-harvest

Corresponding Author: Gustavo Adolfo González-Aguilar, Coordination of Food Technology of Plant Origin,

Research Center for Food and Development, AC Km 0.6, Road to Victory, AP 1735, 83000, Hermosillo, Sonora, Mexico Fax: +52(662) 280-04-22 
manipulation and stage of ripeness (Kevers et al., 2007).

Information available on changes of individual phenols and carotenoids in papaya during ripening is limited; therefore methods for the determination of the Antioxidant Capacity (AOC) and for the evaluation of the evolution of papaya during ripening are needed. One of the most commonly used AOC techniques are DPPH (2, 2-diphenyl-1-picrylhydrazyl), TEAC (2, 2azino-bis (3-ethylbenzthiazoline-6-sulfonic acid) and Oxygen Radical Absorbing Capacity (ORAC) (CorralAguayo et al., 2008). The first two techniques develop discoloring reactions, which are proportional to the antioxidant capacity in the sample to reduce the radical and are measured using spectrophotometry. With ORAC, a fluorescent protein called fluorescein is used as an oxidable substrate and 2, 2'-azobis (2amidinopropane) (AAPH) is used as a generator of peroxil radicals and $\mathrm{AOC}$ is quantified using a fluorometer. The AOC obtained by these methods are in function of the type and mixture of antioxidants. The objective of this work was to evaluate the effects of maturity stage on physiological and biochemical changes of "Maradol" papaya fruit associated with overall quality.

\section{MATERIALS AND METHODS}

Plant materials: Fresh papaya fruit (1-1.5 Kg) (Carica papaya L. cv. Maradol) was obtained from a commercial fruit distributor in Hermosillo, Sonora, Mexico and transported to the Fresh-cut Laboratory of the Centro de Investigación en Alimentación y Desarrollo, AC (CIAD). Fruit were selected according to their size, color and external ripeness. Afterwards fruit were sanitized with chlorinated water (200 ppm) for $3 \mathrm{~min}$ and were left to dry at room temperature for about $1 \mathrm{~h}$. Fruit were selected subjectively according to surface color and divided in 4 groups of 15 fruit each, where four Ripeness Stages (RS) were established: RS1 represents papaya that is yellow $0-25 \%$; RS2 $>25$ and $50 \%$; RS3>50 and $75 \%$ and RS4>75 and $100 \%$.

Physiological and chemical analysis: Respiration and ethylene production rates were determined using three pieces of papaya fruit which were selected based on their RS. The 3 pieces of papaya were placed in sealed plastic containers for $2 \mathrm{~h}$. Then, using a hypodermic needle, $1 \mathrm{~mL}$ from the headspace was extracted and then injected into a Varian Star $3400 \mathrm{CX}$ gas chromatograph, equipped with the following: A Haysep $\mathrm{N}$ column of $200 \mathrm{~mm}$ in length and internal diameter of $3 \mathrm{~mm} ; 80 / 100 \mu \mathrm{m}$ size; a series of two detectors, one with Thermal Conductivity (TCD) for the quantification of $\mathrm{CO}_{2}$ and the other Flame Ionization (FID) for the detection of ethylene and $\mathrm{N}_{2}$ was utilized as a carrier gas. Temperature conditions were $50^{\circ} \mathrm{C}$ for the column, $70^{\circ} \mathrm{C}$ for the injector, $170^{\circ} \mathrm{C}$ for the $\mathrm{TCD}$ detector and $205^{\circ} \mathrm{C}$ for the FID detector. Concentrations of the standards were $5 \% \mathrm{O}_{2}, 5 \% \mathrm{CO}_{2}$ and $1 \mathrm{ppm} \mathrm{C}_{2} \mathrm{H}_{4}$. To determine the concentration of each gas, the area under the curve was integrated and was compared with the areas of the known standards.

Papaya tissue firmness was measured by puncture method, using a Chatillon Penetrometer, Model DFM50 with an $8 \mathrm{~mm}$ diameter flat-head stainless-steel cylindrical probe. Tissue's opposition force against the penetration was registered on 3 points in the equatorial region of the whole piece of fruit and results were reported in Newtons $(\mathrm{N})$.

The pH, Titratable Acidity (TA) and Total Soluble Solids (TSS) determinations were done following the AOAC (1998) method, where $10 \mathrm{~g}$ of fruit were homogenized in $50 \mathrm{ml}$ of distilled water; the mixture was filtered using organza fabric and $50 \mathrm{~mL}$ of the filtered mixture were taken to quantify $\mathrm{pH}$ and TA using a Mettler (Mod DL21) automatic Tritator. TA was expressed as a percentage of malic acid. TSS were measured directly from the filtered residue, using an Abbe digital refractometer and expressed in ${ }^{\circ}$ Brix.

Skin color was longitudinally determined on four points of each flat side of the fruit, using a Minolta CR300 colorimeter. The $\mathrm{L}^{*}$ value represents the luminosity of the fruit, where $\mathrm{O}=$ Black and $100=$ White. The $\mathrm{a}^{*}$ value ranges from the negative (green) to the positive (red) scale. The $b^{*}$ value could range from negative (blue) to positive (yellow). To know the real color changes of the fruit, $a^{*}$ and $b^{*}$ values were used to calculate the Hue angle ( $\left.{ }^{\circ} \mathrm{Hue}\right)$ and the Chroma (intensity), with the following equation:

$$
\begin{gathered}
{ }^{\circ} \text { Hue }=\operatorname{arctg} \mathrm{b}^{*} / \mathrm{a}^{*} \\
\mathrm{C}=\left[\left(\mathrm{a}^{*}\right)^{2}+\left(\mathrm{b}^{*}\right)^{2}\right]^{1 / 2}
\end{gathered}
$$

Where:

${ }^{\circ} \mathrm{Hue}=0$ represents a purple red

$90^{\circ}=$ Yellow

$180^{\circ}=$ Green-blue

$270^{\circ}=$ Blue

Enzyme assays: PG activity was determined following the method described by Gross (1982), with some modifications. The samples $(10 \mathrm{~g})$ were homogenized in an Ultra Turrax ${ }^{\circledR} \mathrm{T} 25$ with $20 \mathrm{~mL}$ of $1 \%$ sodium bisulfite buffer and $6.0 \mathrm{pH}$. Next, they were filtered and a second wash of the residue was performed with 
$20 \mathrm{~mL}$ of $1 \%$ sodium bisulfite, followed by a third wash with $15 \mathrm{~mL}$ of $1 \mathrm{M} \mathrm{NaCl}$. The extract's $\mathrm{pH}$ was adjusted to 6.0 and then the extract was stirred continuously for 3 hours in a Thermolyne Speci-Mix agitator, at $4^{\circ} \mathrm{C}$. Afterward, it was filtered and was centrifuged at $9400 \mathrm{~g}$ at $4^{\circ} \mathrm{C}$ for $15 \mathrm{~min}$. Enzyme solution $(250 \mu \mathrm{L})$ was mixed well with substrate solution ( $2 \mathrm{mg}$ polygalacturonic acid dissolved in $750 \mu \mathrm{L}$ of sodium acetate buffer $37.5 \mu \mathrm{M}$, $\mathrm{pH} 4.4$ ) and was incubated in water bath at $30^{\circ} \mathrm{C}$ for $2 \mathrm{~h}$. Then the extract was centrifuged at $9400 \mathrm{~g}$ at $4^{\circ} \mathrm{C}$ for $15 \mathrm{~min}$ and $200 \mu \mathrm{L}$ of the supernatant was taken and mixed with $1 \mathrm{~mL}$ of $0.1 \mathrm{M}$ borate buffer at $9.0 \mathrm{pH}$ with $200 \mu \mathrm{L}$ cyanoacetamide $(1 \%)$. Then the mixture was placed in a water bath at $100^{\circ} \mathrm{C}$ for $10 \mathrm{~min}$ and was left to cool down at room temperature. Absorbance was read using an UV-VIS VARIAN CARY 50 BIO spectrophotometer at $276 \mathrm{~nm}$. Various levels of galacturonic acid solution were used to construct the standard curve (0-100 nmoles) for the PG activity assay. PG activity was expressed as Unit $\mathrm{mg} \mathrm{FW}^{-1}$ and one activity unit was defined as the amount of enzyme that releases $1 \mathrm{nmol}$ of reducing groups per $1 \mathrm{~h}$. The assay was conducted three times for each RS.

To measure PME activity, a fruit sample $(10 \mathrm{~g})$ was homogenized with $25 \mathrm{~mL}$ of Tris-Cl $0.1 \mathrm{M}$ buffer at $\mathrm{pH} 8.0$, containing $0.3 \mathrm{M} \mathrm{NaCl}$ in an Ultra Turrax ${ }^{\circledR} \mathrm{T} 25$ and placed in a Thermolyne Speci-Mix agitator at $4^{\circ} \mathrm{C}$ for $30 \mathrm{~min}$, followed by centrifugation at $9400 \mathrm{~g}$ for $25 \mathrm{~min}$ at $4^{\circ} \mathrm{C}$. The enzymatic extract was stored at $-35^{\circ} \mathrm{C}$ until analysis and PME was determined following the method of Rouse and Atkins (1955), with some modifications. This method consists of the evaluation of the activity of the enzyme through titration, using as a substrate $25 \mathrm{~mL}$ of $1 \%$ pectin in $0.1 \mathrm{~N} \mathrm{NaCl}$ at $7.5 \mathrm{pH}$, which was adjusted with $0.1 \mathrm{~N}$ $\mathrm{NaOH}$. The pectin was placed at water bath at $30^{\circ} \mathrm{C}$ for $10 \mathrm{~min}$ and $2 \mathrm{~mL}$ of the extract was added. Decrement of $\mathrm{pH}$ caused by the carboxylic groups, generated by the PME during the desertification of the pectin solution were kept constant at a $7.5 \mathrm{pH}$ by titrating the solution with $0.049 \mathrm{~N} \mathrm{NaOH}$ for $10 \mathrm{~min}$ at room temperature $\left(24^{\circ} \mathrm{C}\right)$. Titration was performed with an automatic Mettler DL21 titrator. Results were expressed as a unit of PME activity, which is defined as the amount that the enzyme required to hydrolyze $1 \mu \mathrm{mol}$ of carboxyl groups, produced in $1 \mathrm{~mL}$ of pectin substrate per minute.

Biochemical evaluations: Papaya flesh sample $(10 \mathrm{~g})$ was homogenized in $20 \mathrm{~mL}$ of $80 \%$ methanol, using an Ultra Turrax ${ }^{\circledR} \mathrm{T} 25$ basic homogenizer (IKA Works, Willmington, NC) at room temperature. The homogenate flesh was sonicated for $30 \mathrm{~min}$ in a
Bransonic 2210 sonicator (Bransonic Ultrasonic Co., Danbury, CT) and later was centrifuged at $9400 \mathrm{~g}$ for 15 minutes at $4^{\circ} \mathrm{C}$. The supernatant was collected and the precipitate was extracted again with $10 \mathrm{~mL}$ of $80 \%$ methanol, under the conditions previously described. The two supernatants were mixed, filtered using Whatman filter paper No.1 and evaporated in a rotary evaporator at $30^{\circ} \mathrm{C}$. The concentrate was diluted with $6 \mathrm{~mL}$ of $80 \%$ methanol and stored at $-35^{\circ} \mathrm{C}$ to be used in the determination of total phenols, DPPH, TEAC and ORAC. The extraction process was performed in triplicate per each RS.

Total phenols were determined according to Singleton and Rossi (1965), with some modifications. Sample of $50 \mu \mathrm{L}$ were taken from a 2:8 dilution with $80 \%$ methanol) and $3 \mathrm{~mL}$ of HPLC-grade water and $250 \mu \mathrm{L}$ of Folin-Ciocalteu $1 \mathrm{~N}$ (1:1) reactive were added. After $5 \min 750 \mu \mathrm{L}$ of $20 \% \mathrm{Na}_{2} \mathrm{CO}_{3}$ was added, followed by $950 \mu \mathrm{L}$ of HPLC-grade water; shaken in a vortex and kept in the dark for 30 minutes. Absorbance was read using an UV-VIS VARIAN CARY 50 BIO spectrophotometer, at a wavelength of $765 \mathrm{~nm}$. Results were expressed in $\mathrm{mg}$ of Gallic Acid Equivalents $(\mathrm{GAE}) / 100 \mathrm{~g}$ of Fresh Weight (FW). Analyses were performed in triplicate per each RS.

DPPH was determined according to the BrandWilliams et al. (1995) technique, with some modifications. The stock solution was prepared by mixing $2.5 \mathrm{mg}$ of DPPH radical with $100 \mathrm{~mL}$ of pure methanol. The solution was adjusted at an absorbance of $0.7 \pm 0.02$ at $515 \mathrm{~nm}$. Trolox (6-hydroxy-2, 5, 7, 8tetramethylchromane-2-carboxylic) was used as a standard and $80 \%$ methanol was used as a blank, $3.9 \mathrm{~mL}$ of DPPH radical were placed in a test tube and $100 \mu \mathrm{L}$ of the extract (2:8 dilution) were added. The mixture was shaken in a vortex and kept 30 min in the dark. Absorbance was then read in an UV-VIS VARIAN CARY 50 BIO spectrophotometer, at a wavelength of $515 \mathrm{~nm}$. Results were expressed in $\mathrm{EC}_{50}$ (concentration of antioxidant required to reduce the absorbance of the radical by $50 \%$ ) in $\mathrm{gFW} \mathrm{mL}^{-1}$. Analyses were performed in triplicate per each RS.

TEAC value was determined according to Miller et al. (1996) and Re et al. (1998). ABTS ${ }^{\circ+}$ cation was generated through the interaction of $19.2 \mathrm{mg}$ of ABTS (2'2-azino-bis(3-ethylbenzotriazoline-6-sulfonic acid)), dissolved in $5 \mathrm{~mL}$ of HPLC-grade water and $88 \mu \mathrm{L}$ of potassium persulfate $\left(\mathrm{K}_{2} \mathrm{~S}_{2} \mathrm{O}_{8}\right)(0.0378 \mathrm{~g}$ $\mathrm{mL}^{-1}$ ). It was incubated in the dark at room temperature for $16 \mathrm{~h}$; then $1 \mathrm{~mL}$ of ABTS activated radical was taken and $88 \mathrm{~mL}$ of ethanol was added. The radical was adjusted at an absorbance of $0.7 \pm 0.02$ at $734 \mathrm{~nm}$. The reaction was initiated adding $2970 \mu \mathrm{L}$ of $\mathrm{ABTS}^{\circ+}$ and 
$30 \mu \mathrm{L}$ of the extract or Trolox standard solution in methanol and. absorbance was monitored at $734 \mathrm{~nm}$ at 1 and $6 \mathrm{~min}$. The percentage of inhibition was calculated and results were expressed as $\mu \mathrm{mol}$ of ET/100 gFW.

ORAC value was determined according to RoblesSanchez et al. (2009). AAPH was used as peroxyl radical generator, fluorescein as fluorescent probe and Trolox as standard. The reaction mixture contained $100 \mu \mathrm{L}$ of extracts, $1.65 \mathrm{~mL}$ of $75 \mathrm{mM}$ phosphate buffer $(\mathrm{pH} 7)$, $150 \mu \mathrm{L}$ of $0.8 \mathrm{M}$ AAPH, $100 \mu \mathrm{L}$ of $0.106 \mu \mathrm{M}$ fluoresce in and phosphate buffer was used as a blank. Samples, phosphate buffer and fluoresce in were pre-incubated at $37^{\circ} \mathrm{C}$ for $15 \mathrm{~min}$. AAPH was added to start the reaction and every $5 \mathrm{~min}$ the fluorescence was measured and recorded until the fluorescence of the last reading declined to less than $5 \%$, respect to initial. The excitation and emission wavelength was set at 484 and $515 \mathrm{~nm}$, respectively and each extract measurement was repeated 3 times. The values were calculated by using a regression equation between the Trolox concentration and the net area under the fluoresce in decay curve and were expressed as Trolox equivalents ( $\mu$ mol TE) per $100 \mathrm{gFW}$. The experiment was repeated at least 3 times during the 2009 season.

Statistical analysis: All determinations were conducted at least three times. Results were analyzed by multiple comparisons through A Variance Of Analysis (ANOVA) and the statistical significance through the Duncan's test. Differences in $\mathrm{p} \leq 0.05$ were considered to be significant. The program Number Cruncher Statistical System version 6.0 software (NCSS, LLC) was used.

\section{RESULTS}

Respiration rate $\left(\mathrm{CO}_{2}\right.$ production) and ethylene production: As expected, the lowest respiration rate was observed in green fruit (RS1) followed by RS2, 3 and 4 (Table 1). These fruit had a respiration rate twofold higher $(15.4 \mathrm{~mL} \mathrm{CO} / \mathrm{kg} . \mathrm{h})$ than fruit from $\mathrm{RS} 1$ ( $7.8 \mathrm{~mL} \mathrm{CO} / \mathrm{kg} . \mathrm{h})$. The respiration rate coincided with the ethylene production which increased with the RS of fruit. The highest production of ethylene was observed in $\mathrm{RS} 3$ fruit $\left(0.91 \mu \mathrm{L} \mathrm{C} \mathrm{C}_{2} \mathrm{H}_{4} / \mathrm{kg} . \mathrm{h}\right)$, followed by $\mathrm{RS} 4$ (0.75 $\left.\mu \mathrm{LC}_{2} \mathrm{H}_{4} / \mathrm{kg} . \mathrm{h}\right)$ (Table 1).

Firmness: Firmness of papaya flesh tended to diminish with maturity stage and initial values of fruit (RS1), decreasing from 3.9-1.4 N (RS4) (Table 1). However, it is important to point out that although fruit in RS4 presented less firmness, its physical appearance and response to manual pressure was good according to the subjective evaluation. The last fruit was considered the most attractive and acceptable for the consumers.
Table 1: Production of $\mathrm{CO}_{2}$ and $\mathrm{C}_{2} \mathrm{H}_{4}$ and changes in firmness in papaya (Carica papaya, L. cv. Maradol) in four stages of ripeness. Mean values in each column followed by a different letter at each ripeness stage are significantly different $(\mathrm{p}<0.05)$

\begin{tabular}{lcll}
\hline Ripeness stage & $\begin{array}{l}\mathrm{CO}_{2} \\
\left(\mathrm{~mL} \mathrm{CO}_{2} / \mathrm{kg} . \mathrm{h}\right)\end{array}$ & $\begin{array}{l}\mathrm{C}_{2} \mathrm{H}_{4} \\
\left(\mu \mathrm{L} \mathrm{C} \mathrm{C}_{2} \mathrm{H} 4 / \mathrm{kg} . \mathrm{h}\right)\end{array}$ & $\begin{array}{l}\text { Firmness } \\
(\mathrm{N})\end{array}$ \\
\hline $1(0-25 \%$ yellow) & $7.94 \mathrm{a}$ & $0.1988^{\mathrm{a}}$ & $6.5 \mathrm{a}$ \\
$2(>25$ and 50\% yellow) & $11.51 \mathrm{~b}$ & $0.5090 \mathrm{~b}$ & $3.9 \mathrm{~b}$ \\
$3(>50$ and 75\% yellow) & $14.80 \mathrm{c}$ & $0.9108 \mathrm{c}$ & $1.9 \mathrm{c}$ \\
$4(>75$ and 100\% yellow) & $15.41 \mathrm{c}$ & $0.7553 \mathrm{c}$ & $1.4 \mathrm{c}$ \\
\hline
\end{tabular}

pH, TA and TSS: Maturity stage of papaya did not show a significant effect on $\mathrm{pH}$ values, which represents the presence of acidic groups, including organic acids, phenols and amino acids (Table 2). It was observed that in $\mathrm{RS} 1, \mathrm{pH}$ was 6.1 and increased to 6.4 in RS4 (Table 2). TSS varied from 5.4 in RS1-9.49.6 for RS3 and RS4, respectively. TA values did not show significant changes in the different maturity stages of papaya fruit.

Color: Hue angle $\left({ }^{\circ} \mathrm{Hue}\right)$ represents changes in color of fruit, which ranges from $0=$ Red, $90=$ Yellow, $180=$ Green-blue and $270^{\circ}=$ Blue. ${ }^{\circ}$ Hue value tended to change according to the RS, showing a minimum difference between the RS3 and 4 (Table 2); however, in general, there was a decrease in color (from 124-85). Chroma (C) levels describe the degree of saturation or intensity of color. Results obtained shows that papaya fruit increased their color intensity to similar levels in RS3 y 4, with values ranging from 29-61. These fruits were in good conditions, without apparent mechanical damages in their surface.

Enzyme assays: The highest PG activity was observed in fruit RS4 $\left(22.48 \mathrm{U} \mathrm{gFW}^{-1}\right)$ and the lowest activity was in the RS1 (8.14 $\mathrm{U} \mathrm{gFW}^{-1}$ ) (Fig. 1A). This enzyme is commonly related with fruit softening and increases at the beginning of pectin's desesterification in ripened fruit. PME removes metoxyl groups from small ramifications of pectin or from partially esterified homogalacturonanes changing pectin's solubility, making it more sensitive to the attacks of other enzymes. PME activity usually initiates before that of PG. Figure 1B shows PME's activity in papaya flesh at various RS. PME activity increased gradually at RS1, RS2 and RS3; but decreased to $0.56 \mathrm{U} \mathrm{gFW}^{-1}$ in fruit of RS4.

Biochemical evaluations: Total phenolic contents of papaya fruit decreased with fruit ripening, with the highest values in RS1 (471.97 and $1.91 \mathrm{mgEAG} / 100$ $\mathrm{gFW}$ ) and the lowest in RS4 (358.67 and 0.88 mgEAG/100 $\mathrm{gFW}$ ) in skin and flesh, respectively (Fig. 2). Commonly, phenols presented in higher concentrations in fruit skin than in flesh. 
Am. J. Agri. \& Biol. Sci., 5 (2): 194-203, 2010

Table 2: Changes in pH, AT, SST and color parameters ( $\mathrm{L}^{*}, \mathrm{a}^{*}, \mathrm{~b}^{*},{ }^{\circ} \mathrm{Hue}$ and $\left.\mathrm{C}\right)$ in papaya (Carica papaya, L. cv. Maradol) in four stages of ripeness. Mean values in each column followed by a different letter at each ripeness stage are significantly different $(\mathrm{p}<0.05)$

\begin{tabular}{|c|c|c|c|c|c|c|c|c|}
\hline Ripeness stage & $\mathrm{pH}$ & AT & SST $\left({ }^{\circ}\right.$ Brix $)$ & $\mathrm{L}^{*}$ & $a^{*}$ & $b^{*}$ & ${ }^{\circ} \mathrm{Hue}$ & $\mathrm{C}$ \\
\hline $1(0-25 \%$ yellow $)$ & $6.141 \mathrm{a}$ & $0.074 \mathrm{a}$ & $5.4 \mathrm{a}$ & $40.01 \mathrm{a}$ & $-16.20 \mathrm{a}$ & $24.86 a$ & $124.69 \mathrm{a}$ & $29.68 \mathrm{a}$ \\
\hline 2 (>25 and $50 \%$ yellow) & $6.207 \mathrm{a}$ & $0.062 \mathrm{~b}$ & $8.7 \mathrm{~b}$ & $53.30 \mathrm{a}$ & $-10.98 \mathrm{a}$ & $43.98 \mathrm{a}$ & $105.00 \mathrm{~b}$ & $48.08 \mathrm{~b}$ \\
\hline 3 ( $>50$ and $75 \%$ yellow) & $6.302 \mathrm{a}$ & $0.056 \mathrm{~b}$ & $9.4 \mathrm{~b}$ & $60.73 b$ & $2.74 \mathrm{~b}$ & $62.79 \mathrm{~b}$ & $87.50 \mathrm{c}$ & $60.50 \mathrm{c}$ \\
\hline 4 (>75 and $100 \%$ yellow) & $6.401 \mathrm{a}$ & $0.048 \mathrm{~b}$ & $9.6 \mathrm{~b}$ & $63.47 \mathrm{~b}$ & $4.86 \mathrm{~b}$ & $66.40 \mathrm{~b}$ & $85.81 \mathrm{c}$ & $61.66 \mathrm{c}$ \\
\hline
\end{tabular}

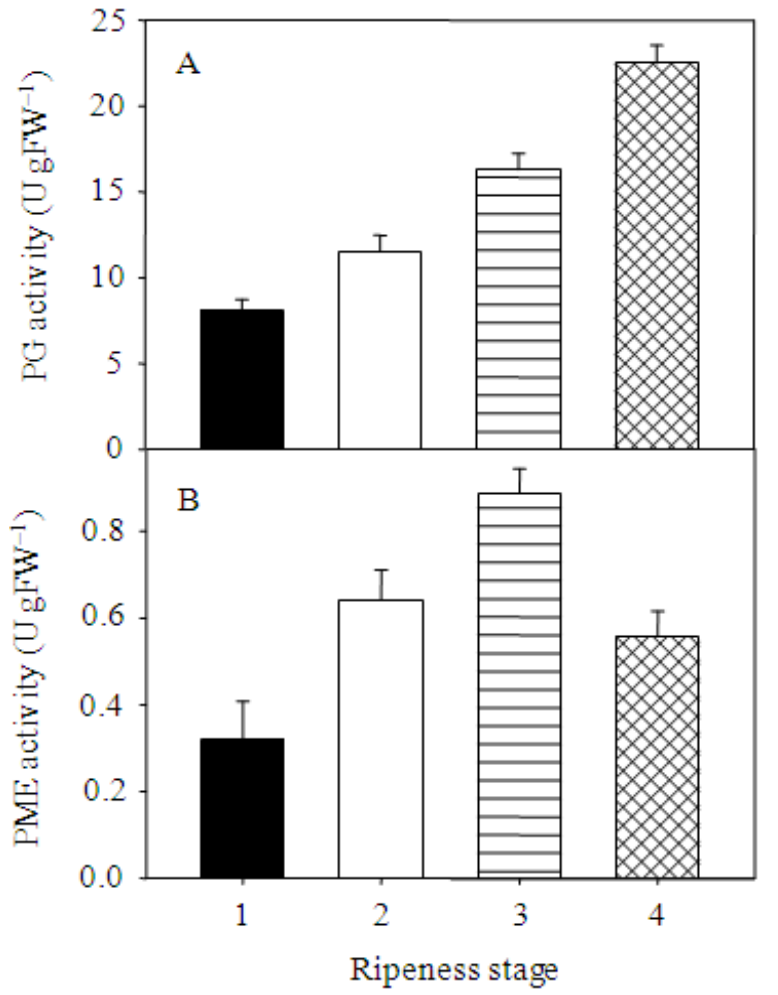

Fig. 1: Activities of polygalacturonase (A) and pectinmethylesterase (B) in papaya (Carica papaya, L. cv. Maradol) in four stages of ripeness. Data shows are means of at least three determinations and error bars indicate the standard deviation, expressed as $\mathrm{U} \mathrm{g} \mathrm{FW}^{-1}$

$\mathrm{EC}_{50}$ expresses the amount of antioxidants required to reduce by $50 \%$ the initial concentration of DPPH radical. Results obtained in the measurement of the AOC of papaya, expressed as $\mathrm{EC}_{50}$, show that RS1 presented the highest antioxidant capacity $(0.116 \mathrm{gFW}$ $\mathrm{mL}^{-1}$ ) in skin, while flesh registered $0.313 \mathrm{gFW} \mathrm{mL}{ }^{-1}$. The lowest AOC was recorded in RS4, with 0.1378 and $0.616 \mathrm{gFW} \mathrm{mL} \mathrm{m}^{-1}$ for skin and flesh, respectively (Fig. 3A).

The greatest AOC in papaya fruit was recorded at RS1 ripeness, in both the skin and flesh (593.77 and $160 \mu \mathrm{MET} / 100 \mathrm{gFW}$ ), while the lowest value was at RS4 (547.88 and 116.02 $\mu \mathrm{MET} / 100 \mathrm{gFW}$ ) (Fig. 3B).

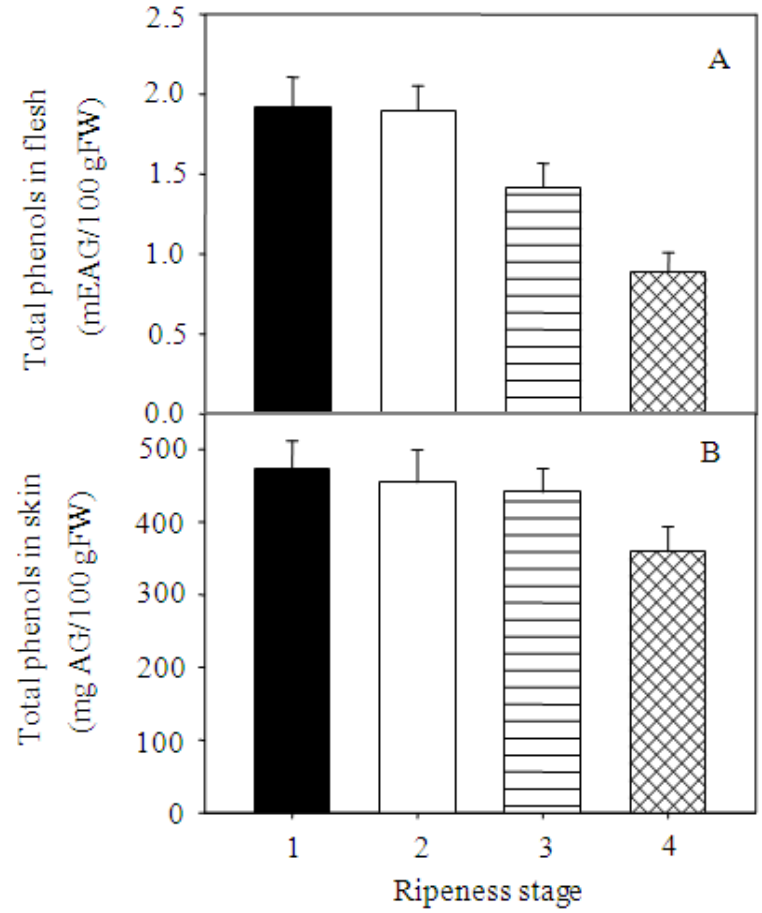

Fig. 2: Totals of phenol in papaya fresh (A) and skin (B) (Carica papaya, L. cv. Maradol) in four stages of ripeness. Data shows are means of at least three determinations and error bars indicate the standard deviation, expressed as $\mathrm{mEAG} / 100 \mathrm{gFW}$

The antioxidant capacity assessed by ORAC increased as the fruit matured, showing that RS1 had $1065 \mu \mathrm{mTE} / 100 \mathrm{gFW}$, while RS4 had $1714 \mu \mathrm{mTE} / 100 \mathrm{gFW}$ (Fig. 3C).

\section{DISCUSSION}

Respiration rate of "Maradol" papaya fruit was similar to that reported in papaya cv. Solo (Paull et al., 1997) with values ranging between $15-35 \mathrm{~mL} \mathrm{CO}_{2} / \mathrm{kg}$.h at $20^{\circ} \mathrm{C}$ (Lam, 1990). Several studies on tropical fruit like mango and papaya observed that the higher the level of ripeness and/or storage temperature, the higher the respiration rate (Rivera-Lopez et al., 2005). 


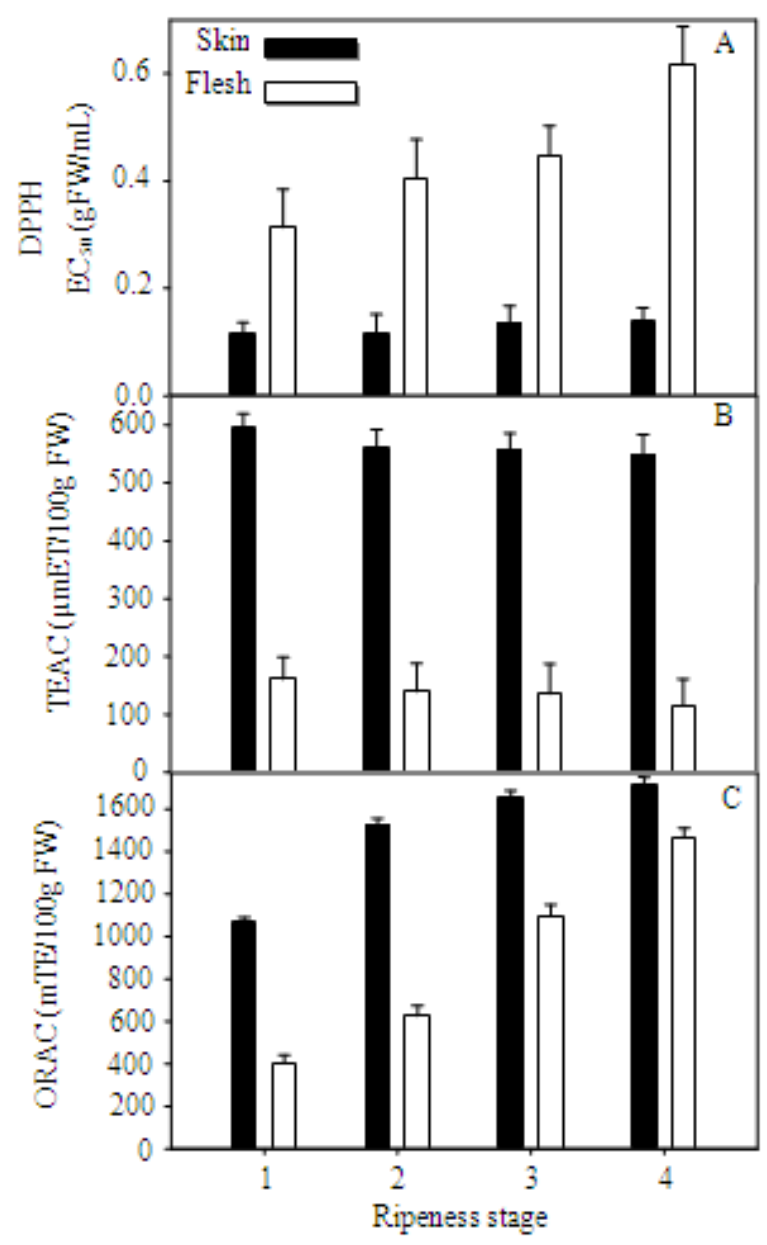

Fig. 3: Antioxidant capacity in papaya fresh and skin (Carica papaya, L. cv. Maradol) in four stages of ripeness through DPPH (A), TEAC (B) and ORAC (C). Data shows are means of at least three determinations and error bars indicate the standard deviation

The beginning of ripeness is usually accompanied by an increase of fruit respiration. Climacteric fruits such as papaya are characterized by an increment in their respiration and ethylene biosynthesis patterns during the ripeness process (Lelievre et al., 1997). In general, a series of events and reactions occur during the ripeness process, where molecules with high molecular weight (such as starch) are degraded, resulting in molecules with low molecular weight (such as sugars and organic acids, among others). Nevertheless, it is important to point out, that if fruit storage conditions are not appropriate, metabolism accelerates and could exhaust its energetic reserves, resulting in the loss of nutritional value of the fruit (Gonzalez-Aguilar et al., 2009).
Ethylene plays an important role in maturation and ripeness. When fruit initiates the ripeness process, small amounts of ethylene $(0.1 \mathrm{ppm})$ can have a profound physiological effect on the fruit, because of its effect on the synthesis of enzymes responsible for physical, chemical and metabolic changes in plant tissue, which influences both firmness and taste of the fruit (Dunkley and Kerith, 1998). Mondal et al. (2008) observed that in guava in different RS, the production rate of ethylene increased reaching the climacteric point and then decreased, resulting in firmness loss, due to the activation of enzymes such as PG and PME.

One of the most important factors that affect firmness is the modification in cell walls of fruit and their degradation by pectolitic enzymes. Paull et al. (1999) observed an increase in the solubilization of pectin and hemicelluloses with a concomitant firmness loss during ripening of papaya which was enhanced with time and storage temperature. Similar patterns in firmness loss were observed recently in papaya cultivars with respect to our study (Nunes et al., 2006). Reduction of firmness observed in papaya correlated with the reduction of ${ }^{\circ} \mathrm{Hue}$, but the change in color from green to yellow was not always present.

Texture changes have been related to the increase of cell-wall degrading enzymes, which are ethylene dependent. Other studies have reported that firmness loss is caused by the action of PME that remove methyl groups from esterifies galacturonic acids that increase with fruit ripening and enhance the accessibility of PG to its pectic substrate and $\beta$-galactosidase activity that increased during the last stages of ripeness (Karakurt and Huber, 2003). Lazan et al. (1989) and Chisari et al. (2009) observed that the loss of firmness appears first in the internal and later in the external mesocarp, attributing this pattern to the lack of synchronism in the degradation of pectin and hemicelluloses, suggesting that solubilization and depolymerization are two independent events in which PG is responsible for the solubilization of pectins, but not causal of fruit softening.

PG presented the greatest activity in papaya fruit flesh with a RS4 (22.48 $\left.\mathrm{U} \mathrm{g} \mathrm{FW}^{-1}\right)$ and the lowest activity at a RS1 (8.14 $\mathrm{U} \mathrm{g} \mathrm{FW}^{-1}$ ) (Fig. 1A). It has been reported that PG activity increases at the beginning of pectin's desesterification in ripe fruit and its activity has been correlated with softening of other fruit during ripening (Lohani et al., 2004).

PME removes metoxyl groups from small ramifications of pectin or from partially esterified homogalacturonanes. When separating methyl esters, PME not only provides a substrate for PG's action, but also modifies the $\mathrm{pH}$ from cell walls, promoting the 
action from other enzymes (Chisari et al., 2009). Figure 1B shows PME's activity in papaya flesh at various RS, where this activity increased gradually at $\mathrm{RS} 1, \mathrm{RS} 2$ and RS3; but decreased to $0.56 \mathrm{U} \mathrm{gFW}^{-1}$ at RS4. A similar behavior has been observed in melons, grapefruits, peaches, kiwis, apples and papaya, where PME's activity in vitro decreased during ripening (Chisari et al., 2009).

Organic acids provide most of the hydrogen ion sand normally decrease with ripening, producing an increase in pH. Studies performed by Sanudo Barajas et al. (2008) obtained a $5.3 \mathrm{pH}$ in green "Maradol" papaya, which shows that $\mathrm{pH}$ tends to change, depending on the variety and the degree of ripeness of the fruit. The $\mathrm{pH}$, TA and TSS results obtained in our study were similar to those obtained by others (Corral-Aguayo et al., 2008) in whole papaya, TSS tended to increase, while TA tended to decrease with fruit maturation. Storing fruit at low or high temperatures can affect negatively the TSS, as a result of acceleration of ripening (Nunes et al., 2006).

The highest color changes are observed when fruit ripe and, in general, the loss of chlorophyll makes yellow and red tones more evident, where carotenoids and other pigments are responsible for these colors. The $\mathrm{L}^{*}$ value represents the luminosity or brightness and it was observed that papaya skin presented significant statistical differences $(p \leq 0.05)$ between the RS1 and RS4 levels, with a tendency to increase, which corresponds to the change of values from 0 to 100 (from dark to light). Nevertheless, this change was minimum in RS3 and RS4 (Table 2). A similar pattern was observed in tomatoes (Marquez and Cortes, 2007) and apples (Rizzolo et al., 2006), where luminosity was higher in ripened fruit. Parameter a* shows important changes in the various RS, ranging from negative (green) to positive (red) values, which indicates the loss of chlorophyll and the biosynthesis of carotenoids in the fruit (Yahia and Ornelas-Paz, 2009). With respect to parameter $b^{*}$, this was used to measure the changes in the fruit from blue to yellow colors and it is possible to observe that in RS1 and 4 exists a considerable change in color, but from RS3-4 there was no significant difference. The result of the increase on the values of parameters $a^{*}, b^{*}$ and $L^{*}$ was similar to the results obtained in studies performed by Ornelas-Paz et al. (2008), where $\mathrm{L}^{*}$ is correlated with the carotenoid content in the mesocarp of "Manila" mango.

${ }^{\circ}$ Hue value tended to change according to the RS, showing a minimum difference between the RS3 and RS4 (Table 2); however, in general, there was a decrease in color (from 124-85). Ornelas-Paz et al. (2008) correlated the reduction of Hue values with the contents of the major carotenoids present in mango. Chroma levels describe the degree of saturation or intensity of color. Results obtained show that papaya fruit increased their color intensity from 29-61 in RS3 and RS4.

Fruits and vegetables contain a great number of essential components, which promote health in humans, because of their beneficial effect against certain diseases, especially several cancer pathologies, acting as antivirals, anti-inflammatories and stimulators of immune response; some of these compounds include phenols (Yahia, 2009). Total phenolic contents of papaya in different RS decreased with fruit ripening, the highest values were recorded in RS1 (471.97 and $1.91 \mathrm{mgEAG} / 100 \mathrm{gFW})$ and the lowest in RS4 (358.67 and $0.88 \mathrm{mgEAG} / 100 \mathrm{gFW}$ ) in skin and flesh, respectively (Fig. 2). This pattern was similar to that observed in nectarines, peaches and plums, where phenolic contents were 2-6 times greater in the skin than in the flesh (Gil et al., 2002).

Mahattanatawee et al. (2006) analyzed different tropical fruits and found that ripened papayas (cv. Red Lady) contained the lowest amount of phenolic compounds, which coincides with our study performed recently with eight horticultural crops (Corral-Aguayo et al., 2008). Phenolic compounds can act as antioxidants and their activity is determined according with the chemical structure that posses. The reason of the difference between the results obtained in different tropical fruits might be because this capacity increases according to the number of hydroxyls present in fruit and their concentration has been correlated with the antioxidant ability of different types of fruit (Wang et al., 2008).

Corral-Aguayo et al. (2008) measured the AOC of "Maradol" papaya, obtaining higher values than those obtained in the present study. It is important to point out that this study used methanol as a solvent, therefore results represent the AOC of hydrophylic compounds (like ascorbic acid and phenolic compounds) as well as of those compounds that are not soluble in water, therefore, perhaps the values were lower because they did not react significantly with DPPH radical. On the other hand, Mahattanatawee et al. (2006) observed that in green papaya (cv. Red Lady) AOC is higher than in ripe papaya of the same variety, which is in agreement with our results. Studies performed by Gancel et al. (2008) in naranjilla indicated that the AOC measured as ED50 (dilution required to reduce by 50\% the initial concentration of DPPH radical) was higher in flesh than in skin, which contrasts with the results that we obtained in papaya, where the highest AOC was observed in the skin. The reason for this could be the 
interaction of phenolic compounds, organic acids and sugars, as well as the variety and atmospheric conditions, which results in greater AOC. Li-Chen et al. (2006) concluded that the AOC obtained in the skin of red pitayas could be the result of the high content and type of phenols (betalains) present in the fruit, because an increment of hydroxyl groups in their molecular structure is related with the increase of AOC.

It is recommended to use different techniques for the AOC evaluation of fruits and vegetables, because of the nature of the different types of compounds present in them and to obtain more reliable results. $\mathrm{ABTS}^{\bullet+}$ or TEAC (Trolox equivalent AOC) methodology is widely used for compounds with hydrophilic or lipophylic nature. Also, the ABTS ${ }^{\bullet+}$ radical has been used to confirm results obtained with DPPH, because both possess similar antioxidant mechanisms. It has been reported that phenolic compounds or ascorbic acids react vigorously with ABTS, while lipophylic compounds make them weaker (Perez-Jimenez et al., 2008).

The highest AOC in "Maradol" papaya was recorded at RS1 ripeness, in both the skin and flesh (593.77 and $160 \mu \mathrm{MET} / 100 \mathrm{gFW}$ ), while the lowest value was at RS4 (547.88 and $116.02 \mu \mathrm{MET} / 100 \mathrm{gpf}$ ) (Fig. 3B). Lako et al. (2007) observed that AOC was higher in papaya cv. Annona muricata, compared with other types of fruits, attributing these values to the considerable amount of flavonoids present $(9$ $\mathrm{mg} / 100 / \mathrm{g}$ ), although generally the content of these compounds is low in fruits.

The AOC assessed by ORAC increased as the fruit matured, showing that RS1 had $1065 \mu \mathrm{mTE} / 100 \mathrm{gFW}$, while RS4 had $1714 \mu \mathrm{mTE} / 100 \mathrm{gFW}$ (Fig. 3C). Similar behavior in "Ataulfo" mangoes showed that antioxidant capacity increased during storage at 5 days (RoblesSanchez et al., 2009), which may reflect the contribution of carotenoids (Yahia and Ornelas-Paz, 2009). However, the study performed by Tabart et al. (2009) in different fruit and vegetable juices concluded that used methods (ABTS, DPPH and ORAC) could provide widely different results, because some measure lipophylic, hydrophyilic compounds and others do not consider physiological cell conditions.

\section{CONCLUSION}

"Maradol" papaya experienced changes in firmness, which is correlated with activity from two of the main enzymes: PG and PME and with the increase of respiration and production of ethylene. Antioxidant capacity, measured using DPPH, ABTS and ORAC techniques, was higher in RS1, which is correlated with higher content of phenolic contents.

\section{ACKNOWLEDGEMENT}

We thank to Mónica Villegas and Reynaldo Cruz for their technical assistance and CONACYT for financial support Grant No. 80511.

\section{REFERENCES}

AOAC., 1998. Official Methods of Analysis. Association of Official Analytical Chemists, Washington, DC.

Brand-Williams, W., M.E. Cuvelier and C. Berset, 1995. Use of a free radical method to evaluate antioxidant activity. Lebensm. Wiss. Technol., 28: 25-30.

Chisari, M., A.C. Silveira, R. Barbagallo, G. Spagna and F. Artes, 2009. Ripening stage influenced the expression of polyphenol oxidase, peroxidase, pectin methylesterase and polygalacturonase in two melon cultivars. Int. J. Food Sci. and Tech., 44: 940-946.

Corral-Aguayo, D.R., M.E. Yahia, A. Carrillo-Lopez and G. Gonzalez-Aguilar, 2008. Correlation between some nutritional components and the total antioxidant capacity measured with six different assays in eight horticultural crops. J. Agric. Food Chem., 56: 10498-10504.

Dunkley, H.M.G. and D. Kerith, 1998. ACC oxidase from Carica papaya: Isolation and characterization. Physiol. Plantarum, 103: 225-232.

Gancel, A.L., P. Alter, C. Dhuique-Mayer, J. Rualesand and F. Vaillant, 2008. Identifying carotenoids and phenolic compounds in Naranjilla (Solanum quitoense Lam. var. Puyo hybrid), an Andean fruit. J. Agric. Food Chem., 56: 11890-11899.

Gil, M.I., F.A. Tomas-Barberan, B. Hess-Pierce and A.A. Kader, 2002. Antioxidant capacities, phenolic compounds, carotenoidsand vitamin $\mathrm{C}$ contents of nectarine, peach and plum cultivars from California. J. Agric. Food Chem., 50: 4976-4982.

Gonzalez-Aguilar, G.A., M.A. Martinez-Tellez, G.I. Olivas, E. Alvarez-Parrilla and L.A. de la Rosa, 2008. Bioactive compounds in fruits: Health benefits and effects of storage conditions. Postharv. Stewart Rev., 4: 1-10.

Gonzalez-Aguilar, G.A., J.F. Ayala-Zavala, L.A, de la Rosa and E. and E. Alvarez-Parrilla, 2009. Phytochemical Changes in the Postharvest and Minimal Processing of Fresh Fruits and Vegetables. In: Fruit and Vegetable Phytochemicals, De La Rosa, L.A., E. Alvarez-Parrilla and G.A. Gonzalez-Aguilar (Ed.). Wiley-Blackwell, USA., pp: 309-340. 
Gross, K.C., 1982. A rapid and sensitive method for assaying polygalacturonase using 2cyanoacetamide. Hortic. Sci., 17: 933-934.

$\mathrm{Hu}, \mathrm{F}$., 2003. Plant-based foods and prevention of cardiovascular disease: An overview. Am. J. Clin. Nutr., 78: 544-551.

Karakurt, Y. and D.J. Huber, 2003. Activities of several membrane and cell-wall hydrolases, ethylene biosynthetic enzymes and cell wall polyuronide degradation during low-temperature storage of intact and fresh-cut papaya (Carica papaya) fruit. Postharvest Biol. Technol., 28: 219-229.

Kevers, C., M. Falkowski, J. Tabart, J.O. Defraigne, J. Dommes and J. Pincemail, 2007. Evolution of antioxidant capacity during storage of selected fruits and vegetables. J. Agric. Food Chem. 55: 8596-8603.

Lako, J.T., V. Craige, M. Wahlqvist, N. Wattanapenpaiboon, S. Sotheeswaran and R. Premier, 2007. Phytochemical flavonols, carotenoids and the antioxidant properties of a wide selection of Fijian fruit, vegetables and other readily available foods. Food Chem., 101: 1727-1741.

Lam, P.F., 1990. Respiration rate, ethylene production and skin color change of papaya at different temperatures. Acta Hortic. (ISHS), 269: 257-266.

Lazan, H., Z.M. Ali, K.S. Liang, K.S. and K.L. Yee, 1989. Poly-galacturonase activity and variation in ripening of papaya fruit tissue with depth and heat treatment. Physiol. Plant, 77: 93-98.

Lelievre, J.M.L., B. Jones, M. Bouzayen and J. Pech, 1997. Ethylene and fruit ripening. Physiol. Plantarum, 101: 727-739.

Li-Chen, W.H.W., C. Yun-Chen, C. Chih-Chung, L. Yu-In and A.H. Ja-an, 2006. Antioxidant and antiproliferative activities of red pitaya. Food Chem., 95: 319-327.

Lohani, S., P.K. Trivedi and P. Nath, 2004. Changes in activities of cell wall hydrolases during ethyleneinduced ripening in banana: effect of 1-MCP, ABA and IAA. Postharv. Biol. Technol., 31: 119-126.

Mahattanatawee, K.M., A. John, G. Luzio, S.T. Talcott, K. Goodner and E.A. Baldwin, 2006. Total antioxidant activity and fiber content of select Florida-grown tropical fruits. J. Agric. Food Chem., 54: 7355-7363.

Marquez, C.J.O. and M. Cortes, 2007. Changes physiological, textural, physicochemical and microestructural of the tree tomato (Cyphomandra betacea S.). AT Posharvest, 14: 7-8.

Miller, N.J., J. Sampson, L. Canadeias, P.M. Bramley and C.A. Rice-Evans, 1996. Antioxidant activities carotenes and xanthophylls. Free Radic. Res., 384: $240-242$.
Mondal, K.S., A.P. Singh, N. Saxena, S.P. Malhotra, K. Dhawan and R. Singh, 2008. Possible interactions of polyamines and ethylene during ripening of guava (Psidium guajava L.) fruits. J. Food Biochem., 32: 46-59.

Nunes, M.C.N., J.P. Emond and J.K. Brecht, 2006. Brief deviations from set point temperatures during normal airport handling operations negatively affect the quality of papaya (Carica papaya) fruit. Postharv. Biol. Technol., 41: 328-340.

Ornelas-Paz, J.J., M.E. Yahia and A. Gardea, 2008. Changes in external and internal color during postharvest ripening of "Manila" and "Ataulfo" mango fruit and relationship with carotenoid content determined by liquid chromatographyAPcI+- time-of-flight mass spectrometry. Postharv. Biol. Technol., 50: 145-152.

Paull, R., K. Gross and Y. Qiu, 1999. Changes in papaya cell wall during fruit ripening. Postharv. Biol. Technol., 16: 79-89.

Paull, R.E., W. Nishijima, M. Reyes and C. Cavaletto, 1997. Postharvest handling and losses during marketing of papaya (Carica papaya L.). Postharv. Biol. Technol., 11: 165-179.

Perez-Jimenez, J.A., S. Arranz, M. Tabernero, M.E. Diaz-Rubio, J. Serrano, I. Goniand F. SauraCalixto, 2008. Updated methodology to determine antioxidant capacity in plant foods, oils and beverages: Extraction, measurement and expression of results. Food Res. Int., 41: 274-285.

Re, R.P., N.A. Proteggente, A. Pannala, M. Yang and C. Rice-Evans, 1998. Antioxidant activityapplying an improved ABTS radical cation decolonization assay. Free Rad Biol. Med., 26: 1231-1237.

Rivera-Lopez, J., F. Vazquez-Ortiz, J.F. Ayala-Zavala, R. Sotelo-Mundo and G.A. Gonzalez-Aguilar, 2005. Cutting shape and storage temperature affect overall quality of fresh-cut papaya cv. Maradol. J. Food Sci., 70: 482-489.

Rizzolo, A., M. Grassi and P. Eccher Zerbini, 2006. Influence of harvest date on ripening and volatile compounds in the scab-resistant Apple cultivar Golden Orange. J. Hortic. Sci. Biotechnol., 81: 691-699.

Robles-Sanchez, R.M., M.A. Islas-Osuna, H. Astiazaran-Garcia, F. A. Vazquez-Ortiz and O. Martin-Belloso et al., 2009. Quality Index, consumer acceptability, bioactive compounds and antioxidant activity of fresh-cut "ataulfo" Mangoes (Mangifera Indica L.) as Affected by LowTemperature Storage. J. Food Sci., 74: 126-134. 
Rouse, A.H. and C.D. Atkins, 1955. Pectinesterase and pectin in commercial citrus juices as determined by methods used at the Citrus experiment station. Univ. Florida Agric. Exp. Sta. Tech. Bull., 570: 1-19.

SAGARPA, 2008. statistical yearbook of agricultural production. http://www.sagarpa.gob.mx

Sanudo Barajas, J.A., J. Siller Cepeda, T. Osuna Enciso, D. Muy Rangel, G. Lopez Alvarez and J. Labavitch, 2008. Control of ripening in fruits of papaya (Carica papaya L.) with 1methylcyclopropene and 2-chloroethyl phosphonic acid. Rev. Fitotec. Mex., 31: 141-147.

Singleton, V.L. and J.A. Rossi, 1965. Colorimetry of total phenolics with phosphomolybdicphosphotungstic acid reagents. Am. J. Enol. Vitivinicu., 16: 144-158.

Tabart, J., C. Keversa, J. Pincemail, J.O. Defraigne and J. Dommesa, 2009. Comparative antioxidant capacities of phenolic compounds measured by various tests. Food Chem., 113: 1226-1233.
Wang, S.Y., C.T. Chen, W. Sicarappa, Ch. Wang and M. Camp, 2008. Fruit quality, antioxidant capacityand flavonoid content of organically and conventionally grown blueberries. J. Agric. Food Che. 56: 5788-5794.

Yahia, M.E., 2009. The Contribution of Fruit and Vegetable Consumption to Human Health. In: Fruit and Vegetable Phytochemicals, De La Rosa, L.A., E. Alvarez-Parrilla and G.A. Gonzalez-Aguilar (Ed.). Wiley-Blackwell, USA., pp: 3-51.

Yahia, M.E. and J.J. Ornelas-Paz, 2009. Chemistry, Stabilityand Biological Actions of Carotenoids. In: Fruit and Vegetable Phytochemicals, De La Rosa, L.A., E. Alvarez-Parrilla and G.A. Gonzalez-Aguilar (Ed.). Wiley-Blackwell, USA., pp: 177-222. 